\title{
Globalization, Europeanization and Trade in the 1990s: Export Responses of Foreign and Indigenous Manufacturing Companies
}

\section{Frances Ruane and Julie Sutherland* \\ Trinity College, Dublin and University of Wollongong, New South Wales}

\section{Introduction}

Within little more than a decade, the word globalization has gone from being a 'catch-all' term used in the economics media to capture the process of integration in world financial, product and service markets, to a term that is now used widely to describe the impact of increased international integration across a range of fields - from literature to sociology to technology. More recently the term has begun to acquire a pejorative dimension, as 'antiglobalization' has become the slogan of groups critical of what they see as the exploitation by large corporate interests in the developed world of smaller companies in lesser-developed economies. Indeed, this shift in the meaning of globalization has led some economists (for example, Rodrik (2000:177)) to favour the term 'international economic integration' as being 'self evident to economists' and less loaded with value judgments. Were this trend to continue, one could see the word entirely disappear from use as quickly as it appeared, to be replaced with parallel expressions such as 'international social integration' and 'international cultural integration'. This would be a loss in terms of our language as these terms lack the breadth that 'globalization' evokes as well as its strong inter- and cross-disciplinary associations.

Clearly globalization is a phenomenon that is wider than a single discipline. The Oxford English Dictionary (OED) defines globalization as "the act of globalizing", and identifies Webster's Dictionary in 1961 as its source of the use of the word. Webster in turn 
defines "globalize" as "to make worldwide in scope or application" - nothing specifically related to economics or indeed to any particular discipline. The OED's first reference to the written use of the term globalization (with the European 's' spelling) is in The Spectator in 1962 - just four decades ago. The strong economic association with the term in recent times seems to have arisen some 20 years later in the mid-1980s, in the context of increased integration in product and financial markets.

The attraction of 'globalization' as a new word may have stemmed from its potential to capture the increased scale and intensity of international, and in particular economic, relationships in the late 1980s, arising from the cumulative effect of declining trade and capital barriers, reduced transport costs, and rapid development in, and diffusion of, modern electronics-based technology. The word came into widespread use in economics at a time when it was unclear how different the world economy might become as the possibilities of international fragmentation of production extended (Arndt and Kierzkowski: 2001). This extension is increasingly evident in the growth and scale of international trade in manufactured components. Globalization captured the sense that there was something more than incremental change taking place - that all countries would be affected to some degree by the scale of integration, that no activities within countries were immune to the process, and that it could help some countries to leap-frog development stages.

\section{Figure 10.1 near here}

Figure 10.1 illustrates the complexity of the relationships in the globalization process from an economics perspective. It identifies four key elements - trade, foreign direct investment (FDI), labour migration and technology. All feed directly into what we call globalization as well as interacting with each other to enhance the extent of globalization. For example, where traditionally trade theorists looked at trade and factor flows as substitutes in terms of achieving factor price equalization, increasingly we see trade and FDI as 
complements, with the strong growth in intra-firm trade and global outsourcing. Global outsourcing would not have been possible without technology - thus the interconnection between trade and technology. In some instances labour migration has been seen as an alternative to FDI (for example, in Eastern/Western Europe and in the USA/Mexico relationships), and technology has now allowed production to be separated geographically from factor inputs, for example, when Indian software engineers contribute to software services in Europe and the USA without ever leaving India.

Attempts to gauge the extent and depth of globalization have typically relied upon data measuring international trade and investment flows, omitting other less readily quantifiable aspects of global integration. Better globalization indices are required if we are to capture what is a major difference in the way in which economies have become interconnected over the past two decades. Furthermore, if we are to take a broader view of globalization, we need indices that capture the extent to which other non-economic activities have become increasingly internationalized, as these feedback into the economic relationships. One recent 'Globalization Index' 2 tracks economic interconnectedness (economic integration and technology) as well as social and political interconnectedness (personal contacts and political engagement) across sixty-two advanced economies and key emerging markets. While it is easy to criticize the purity of such indices, one must appreciate attempts to measure such important global changes.

During the 1980s we also witnessed a marked increase in the intensity of Europeanization (regional integration within Europe), which has had the effect of redefining the implicit and indeed explicit parameters of economic integration in historic terms. Beginning with the abolition of barriers to trade and factor flows and continuing with the harmonization of fiscal and competition policies, Europe has now created Union-wide institutions and, as of 2002, eleven countries now share a single currency. Throughout this 
process of Europeanization, economic integration has been used as the key vehicle to achieve more fundamental integration in Europe. For economists interested in the world economy, the trends towards increased Globalization and Europeanization have broadened the scope of academic enquiry, increased emphasis on the complexity of economic interdependency both within and between companies and countries, and led to a better understanding of the role that supra-national institutional frameworks can and must play in developing such interdependency.

Globalization from an economic perspective manifests itself in increased international trade, foreign direct investment flows and, to a lesser extent, international migration of labour. But the process of globalizing, even in economic terms, is much more complex than is evident in aggregate data at product or factor level, irrespective of how refined the data are. Many authors have attempted to deal with this complexity by combining studies based on aggregate data (on trade, factor flows, relative prices and wages, etc.) with country or sector case studies or historical examples from specific markets or periods; see for example, Feenstra (1998), Obstfeld (1998), and Williamson (1998).

In the vast literature on globalization, there is great emphasis on the role of multinational corporations (MNCs) in the process. The perceived dominance of MNCs (many of which are headquartered in the US) in certain product and service markets and the extent of global mergers and acquisitions provide, perhaps, some of the main reasons why globalization has attracted its pejorative dimension. While it is certainly the case that a large proportion of world trade takes place through MNCs, access to broader markets has been very important for local companies, which we label LCs. Cross border trade is particularly important for LCs based in smaller economies, such as many potential EU entrants, because in its absence their scale of production would likely be sub-optimal and/or local markets would become overly-concentrated. In either case, domestic competitiveness and/or 
competition could be undermined. There is strong recognition of this effect in EU documents, as trade and competition (anti-trust) policies are seen as twin policy instruments in ensuring competition; see European Commission (1997; Section II-C).

Research into the trade patterns of LCs and MNCs is ongoing, with significant attempts being made to establish national data sets at the company level. For the most part, however, research to date is based on specific country data; see for example, Baily and Solow: 2001. In this Chapter, we use data for Ireland to explore how the process of globalization impacts on LCs as well as MNCs in the context of Europeanization. We use a highly dis-aggregated data set of Irish manufacturing companies, both indigenous and foreign-owned, to investigate the pattern of investment and trade flows as possible evidence of increasing globalization. In particular, we examine the nature of investment flows into Irish manufacturing industry to determine if investment is from a European or global source, and how the resulting export destination patterns of European-owned MNCs (EU MNCs), and non-European owned companies (Non-EU MNCs) contrast with each other and with those of Irish LCs.

In Section 2 we look broadly at recent developments in openness by summarizing trends in merchandise trade and foreign direct investment in a sample of European and nonEuropean countries over the three decades up to 2000. In Section 3 we concentrate our discussion on trade in manufacturing industry, using data that distinguishes between LCs and MNCs operating in Ireland. Given the unprecedented rate of economic development in Ireland in the past decade, which has been strongly driven by MNC activity ${ }^{\square}$, we compare the growth and export trends of those sectors dominated by MNCs with those sectors where LCs are dominant. In Section 4 we examine the sectoral pattern of FDI and export destinations for both LCs and MNCs across three major sectoral categories in Irish manufacturing in order to establish whether their exporting behaviour has involved increased Europeanization or 
globalization. In addition, we note the relationship between the changing export destination pattern of Irish companies in each sector and the performance characteristics of exporting companies relative to non-exporters. Finally, in Section 5 we present some concluding comments based on our analysis.

\section{European globalization}

The growth in international trade in Europe over the past fifty years has been dominated by increased economic, political and social integration through several different phases European Economic Community (EEC), European Community (EC) and European Union (EU) - with additional members joining the six original members during the 1970s, 1980s and 1990s. To examine trends in the degree of trade openness at a national level we use the ratio of merchandise trade (measured as the average of imports and exports) to GDP between 1970 and 2000 as an indicator. While this is the standard indicator used to compute openness, the measure is imperfect in two dimensions. On the one hand, it understates the degree of openness because it includes services in the measure of GDP and excludes them in the measure of trade; this downward bias is increasing with the growth in the services share of GDP. On the other hand, the indicator overstates the degree of openness as the measure of imports and exports include trade in intermediate inputs whereas GDP is a value-added concept. Despite these technical shortcomings the indicator does provide a relative measure of the degree of openness across countries over time.

\section{Table 10.1 near here}

Not surprisingly, the degree of trade openness across the incumbent member countries of the EEC in 1970, some 15 years after the creation of the Common Market, was much higher in the smaller economies (Netherlands and Belgium-Luxembourg) than in the larger economies (France, Germany, and Italy), reflecting the greater need of the former to trade in 
order to meet consumer demands and achieve competitiveness ${ }^{4}$. The period since 1970 has seen the larger economies narrow that gap, although it remains the case that the ratios of the smaller countries are twice those of the larger countries. Since the trade/GDP ratio rose in France, Germany and Italy by 20, 14 and 28 per cent respectively during the 1960 s, there is a clear pattern of increased globalization in terms of merchandise trade, and the ratios for individual countries now well exceed those found prior to World War I (see Feenstra: 1998). This increased openness is regarded as a direct product of the reductions in non-tariff barriers to trade within the EU, the lowering of tariff and non-tariff barriers under the GATT and more recently under the WTO agreements, the lowering of trade transportation costs per unit, the rise in the share of weightless products in consumption, and the growth in the EU market. In 1973 the EEC admitted its first new entrants, Denmark, Ireland, and the UK. Reflecting the patterns of the incumbents, the smaller two countries had significantly higher trade/GDP ratios than the UK in 1970. If we can interpret the 1970s and 1990s as the decades reflecting EEC market-entry and single-market effects respectively, Table 10.1 suggests that all three countries, particularly Ireland, enjoyed a strong EEC-entry trade effect, whereas only Ireland enjoyed a very strong single-market effect. The latter effect is primarily through the increased attractiveness of Ireland as a production base for manufacturing by non-EU MNCs, especially those from the USA; see Krugman (1997), Barry (1999) and Görg and Ruane (1999). But is such an interpretation justified? Sweden and Austria also saw significant increases in their trade ratios during the 1990s when they entered the EU (in strong contrast to Norway which remained outside the EU), but they also enjoyed very substantial increases in trade in the 1970s when they were not EEC members. In effect, Table 10.1 shows that the 1970s is the only decade in which the ratio of merchandise trade to GDP increased for all countries listed. 
Turning to look at some other major OECD countries, we note that the ratios for the US, Japan and Australia are all lower than those for the individual European countries. The US ratio has risen dramatically over the period, with most of this increase (from a low base) taking place in the 1970s. While the ratio for Australia has risen steadily over the period, the Japanese ratio is still below its 1970s level. However, in contrasting EU and non-EU countries it could be argued that these data provide evidence of Europeanization and not Globalization, in the sense that the increased trade is intra-EU and a direct impact of the trade diversion impact of creating an economic trade area in Europe.

How much of the trade in Table 10.1 is extra-EU versus intra-EU? If we apply the average ratio of intra-EU trade to total-EU trade of approximately 60 per cent for small countries and 50 per cent for large countries (European Commission: 1996), and make the assumption that only non-EU trade represents globalisation, it could be argued that Europe is not markedly different from the US in terms of its openness to global trade. This estimate is consistent with the results obtained for 1995, which indicate strongly that the EU-15 as an area at that time was no more globalized in trade terms than was the US (see European Commission: 1997/Table 2).

\section{TABLE 10. 2 near here}

Paralleling the focus on merchandise trade in Table 10.1, we examine foreign direct investment (FDI) in the merchandise goods sector in Table 10.2. It shows the wide variation in the ratio of the average of inward and outward FDI to GDP in different EU countries for the period 1970-2000, and for six sub-periods within that time frame ${ }^{5}$. Again, with the exception of Japan, there has been a marked increase in FDI flows for all countries in the 1990s. As with the trade data, the ratios are generally higher in EU than in non-EU countries and, except for Japan, they have risen very steeply in the six-year period to 2000 . These indicators mask quite different balances between countries as some have large volumes of 
inward- and little outward-FDI, while others have more even volumes flowing in both directions; for example, until the past decade, Ireland had virtually no outward FDI but had exceptionally high levels in inward FDI. If we again apply the ratios of extra-EU to total FDI inflows in the EU to the totals here, and treat only those extra-EU flows as evidence of globalization, we find that in the period since 1985, when this ratio began to decrease, the scale of FDI is not much greater for the larger countries in the EU, with the exception of the UK, than it is for the US (see European Commission: 1996/Chapter 4).

In summary, two of the main indicators used to indicate economic globalization show that while openness in trade and FDI has increased in Europe, much of the increase has involved Europeanization rather than Globalization. That is, trade and FDI flows by EU countries have been concentrated within Europe rather than flowing strongly into and out of the EU. For the remainder of this paper we concentrate on how, in the context of FDI, openness in trade impacts upon Ireland, which has the highest trade openness ratio in Table 10.1. We examine how this openness affects the manufacturing sector by investigating the source of FDI and the resulting export destination patterns of both Irish-owned companies (LCs) and foreign-owned companies (MNCs).

\section{Globalization and exporting at the national level}

How do LCs within an economy fare in the globalization process? They are directly and indirectly affected by the growth of FDI, by the increase in competition on their domestic markets, and by the potential new foreign markets that the globalization process opens up. International organizations would claim that there are very positive benefits from the presence of foreign-owned MNCs operating within the economy (see UNCTAD: 2001). There is a growing empirical literature that examines the extent to which LCs can benefit or lose from foreign direct investment, through the linkage, spillover and crowding-out effects 
generated by MNCs. While some of these studies find evidence of positive effects at the sectoral level, fewer of them find evidence at the plant level, suggesting that positive effects through linkages and demonstration effects may be counterbalanced by negative crowdingout effects (see Görg and Greenaway: 2001).

The data presented in Section 2 have shown that much of the increase in trade and FDI in Europe has involved increased Europeanization rather than globalization, that is, much FDI has been sourced from Europe, and much of the increase in trade flows has been destined for Europe. But are such patterns consistent for an individual country? For a country that receives a relatively large proportion of FDI, the source of FDI and the resulting proportion and direction of trade can have significant implications for indigenous companies on many levels. In order to understand the connections that may exist between FDI and trade for both MNCs and LCs we examine the nature of trade and investment in Ireland, which was ranked the as the most globalized country in the world in $2000^{6}$. The remarkable growth of FDI, particularly in the manufacturing sector, has facilitated an unprecedented level of economic growth in Ireland during the 1990s, as is evident in Figure 10.2. It shows that growth in Ireland in the final five years of the $20^{\text {th }}$ century averaged 8.4 percent, compared with the EU15 average of 2.6 percent (See Barry, Chapter 9, for a discussion of possible explanations for such exceptional growth in Ireland in this period.). Our objective is to examine the source of this FDI in Irish manufacturing, its export patterns, and the resultant changes in LC export patterns.

\section{Figure 10.2 near here}

In particular, we concentrate on how LCs are affected by engaging in exporting as part of the globalization process (see Greenaway and Sapsford: 1994, and Richardson and Rindal:1995), leaving aside the impact that globalization may have on LCs through competition on the local market. As merchandise exports by MNCs have grown, to what 
extent have LCs participated in this growth? Are the LCs tending to operate in the same sectors as MNCs and trade in the same geographic markets? To answer these questions we need to use data that allow us to distinguish company ownership and associate exports with sectors and plants rather than with products.

To study the behaviour of companies we look at data on LCs and MNCs in the Irish manufacturing sector. It could be said that, in terms of globalization, Ireland has had a first mover advantage! It has endured strong outward migration flows for most of the $19^{\text {th }}$ and $20^{\text {th }}$ centuries and strong inward migration over the past decade; high mobility of capital out of and into the economy over different decades, and especially into the manufacturing sector over the past four decades; and high export/import to GDP ratios (both before and after a period of high protection of domestic markets from 1930 to the late 1960s). To set the analysis of the next section in context, we examine here data for the Irish manufacturing sector for the period 1991-98. We chose this period primarily on the grounds of suitable data availability - it is the full extent of the period for which data are available using the NACE Rev. 1 industry classification. It also coincides with a period when the ratio of Ireland's merchandise trade to GDP rose from around 50 per cent to over 67 per cent. Throughout this analysis, we use data on companies with 14 or more employees, as the data for companies with fewer than 14 employees provides a less detailed breakdown of the destination of exports. In the case of each company, we have its majority ownership status; we aggregate all EU-nationality owned companies to generate the foreign category EU MNCs, and aggregate all Non-EU nationality owned companies to form the foreign category Non-EU MNCs. ${ }^{\text {] }}$ Irish-owned companies are labeled LCs. The data also indicate whether output is exported or sold on the Irish market and, if exported, whether it is exported to the EU, which includes the United Kingdom (Ireland's traditional export market), or the Non-EU, which includes the USA (the source of increasing amounts of Irish foreign direct investment). These export data 
have an advantage over traditional trade data in that they are more likely than the trade data to register the final destination market for Irish exports, as the latter often note the country of distribution rather than of consumption.

In order to trace the growth of FDI in Irish manufacturing we look at employment growth rather than output growth, as transfer-pricing issues related to FDI companies in Ireland tend to overstate the relative importance of FDI. The data in Figure 10.3 show that, in the period 1991-98, the total number of employees engaged in manufacturing in Ireland rose by 25 per cent, a rate of growth exceptional by European standards. The rate of growth of inward FDI is reflected in the employment growth in MNCs over the period, which was greater (33 per cent) than that in LCs (18 per cent). This growth resulted in a highly 'open' Irish manufacturing sector, with employment in companies with more than 14 employees being evenly split between MNCs and LCs in 1998.

\section{Figure 10.3 near here}

Employment in EU MNCs remained relatively static, increasing by 3.5 per cent over the period. (This modest increase is the result of two contrasting patterns - a reduction of around 9 per cent in employment in UK-owned companies, Ireland's traditional source of FDI, and an increase in employment in Non-UK European companies of 11 per cent.) In contrast, the growth of employment in Non-EU MNCs far outpaced employment growth in both Irish and EU companies, rising by almost 53 per cent. The principle source of this NonEU employment growth was in USA-owned MNCs, whose employment grew by almost 70 per cent over the period. Thus the pattern of FDI in Ireland between 1991 and 1998 is clear: growth has been concentrated in the Non-EU MNCs, with USA-owned companies in particular showing greater growth than any other ownership group. Based on these simple measures it could be argued that although ownership in the Irish manufacturing sector is more Europeanized overall, it is becoming more globalized. 
Foreign companies that have established in the Irish manufacturing sector have done so in order export their outputs; in 1998 over 92 per cent of MNCs in Irish manufacturing engaged in exporting and almost 92 per cent of their total gross output was exported. The scale of involvement in exporting by LCs is, not surprisingly, much lower; 58 per cent of all LCs engaged in exporting in 1998, the same proportion as in 1991. The proportion of total gross output exported by LCs also remained constant between 1991 and 1998 at 36 per cent, although the exports themselves increased substantially in value terms.

In the context of Ireland becoming a manufacturing platform in Europe for MNCs and of the significant difference in the proportion of output exported by MNCs and LCs, we have analyzed the data to determine whether MNCs and LCs based in Ireland are engaged in exporting into the same markets. As noted above, Irish data allow us to distinguish two different market areas - EU and Non-EU, so that we can observe differences in Europeanisation and globalization patterns.

\section{Figure 10.4 near here}

Figure 10.4 highlights the differences in export destination by ownership between 1991 and 1998. Most notable is the exceptional growth (21 per cent per annum) in total exports by Non-EU MNCs, with total exports by both EU MNCs and LCs growing more slowly (11 per cent and 4 per cent per annum respectively) over the period. The share of exports by LCs to the EU increased slightly, from 71 to 73 per cent of total exports, with exports to the UK falling marginally over the period. Thus LCs are now trading relatively more in EU markets, and their dependence on the traditional UK market has continued to decline. This suggests that LCs are becoming more Europeanized in their export patterns, which is not surprising because of the traditional high share of exports going to the UK and the new geographically-proximate export opportunities that the rest of the EU provides to Irish LCs. The pattern of exporting differs for foreign-owned companies; EU MNCs are now 
exporting a marginally greater proportion to Non-EU countries, with EU-destined exports falling from 83 to 79 per cent of total EU MNC exports between 1991 and 1998. Similarly but on a more marked scale, Non-EU MNCs increased their share of exports to Non-EU destinations from 30 to 38 per cent over the period, with the USA experiencing the fastest export growth rate (albeit from a comparatively low base). This suggests that in the recent period of globalization Non-EU MNCs in particular are using Ireland increasingly as a global and not just an EU export platform.

The above analysis has allowed us to segregate the ownership and export destination patterns in Irish manufacturing in order to ascertain differences between Irish-, EU-, and Non-EU-owned companies. But such aggregation hides the sectoral pattern that underlies the nature of globalization and Europeanization in Irish manufacturing. The pattern of foreign ownership in the Irish manufacturing sector is highly sectorally concentrated, with most NonEU FDI concentrated in the 'high-tech' sectors and EU FDI going into the more traditional manufacturing sectors. Given this FDI pattern, what is the nature of exporting at the sectoral level in Irish manufacturing?

\section{Globalization and exporting at the sectoral level}

When we investigate the degree of sectoral variation across manufacturing in Ireland, we find that the growth of manufacturing sector employment over the 1990s, while substantial overall, differed very widely across sectors. Using the standard NACE Rev. 1 sectoral classification we identify a number of sectors that experienced employment growth in excess of 50 per cent for the period 1991-98. These include the 'high-tech' sectors, namely, Chemicals, Office Machinery \& Computers, Electrical Machinery, Communication Equipment, and Precision Instruments ${ }^{8}$. MNCs account for over 80 per cent of total sector 
employment in all of these sectors except Electrical Machinery, where they account for over 70 per cent.

Using this technology and MNC division we classify the Irish manufacturing sector into three sub-sectors - the two high-tech, MNC-dominated sectors, namely, 'Chemicals' and 'Electronics', and the low-tech, LC-dominated sector 'Other Manufacturing, reason for separating manufacturing into these three sub-groups is that Irish policy has been promoting FDI investment in the Chemicals and Electronics sectors for over thirty years viewing them as sectors which were growing rapidly in global terms and in which production in Ireland could be competitive, given the high value-added to volume ratios in these sectors ${ }^{10}$. We next turn to compare the globalization and Europeanization trends in the hightech Chemicals and Electronic sectors and the low-tech Other Manufacturing sector.

\section{Figure 10.5 near here}

The distinctive feature of Irish manufacturing over the period considered is the exceptional growth in the Electronics sector. The annual average rate of growth of employment in LCs in the Electronics sector companies was approximately 13 per cent between 1991 and 1998. Whilst LCs led the employment growth in Electronics, both EU- and Non-EU MNCs also had significant growth. Annual employment growth in the high-tech Chemicals sector was also high during the period, with Non-EU MNCs showing faster growth than Irish and EU-companies. The distinctive feature of these two sectors is the dominance of Non-EU ownership; in 1998, over 67 and 60 per cent of total employment in Electronics and Chemicals respectively was in Non-EU MNCs. The main source of this investment is the United States, as is evident in Table 10.3, which shows the very large proportion of US foreign direct investment in these sectors that went to Ireland in 1998. In the context of the size of the Irish market, these shares indicate the significance of Ireland's role as an export platform in Europe for these sectors. 


\section{Table 10.3 near here}

In contrast to these high-tech manufacturing sectors, LCs dominate the low-tech Other Manufacturing sector. Relative to Electronics and Chemicals, employment growth in this sector was minimal, with employment in EU MNCs actually declining over the period. By 1998, 67 per cent of employment in Other Manufacturing was in LCs.

Section 3 noted the changing nature of the destination of exports at the manufacturing industry level, and in particular the trend of Non-EU MNCs towards exporting more of their output to Non-EU destinations. Using the disaggregation of sectors dominated by Non-EU MNCs (Electronics and Chemicals) and LCs (Other Manufacturing), the sectoral patterns underlying the export destinations become clearer.

Table 10.4 highlights the export destination pattern of the sub-sectors, which show distinctive trends over the period considered. The rapid export growth in the LC Electronics sector (24 per cent per annum) is increasingly global rather than European, with exports to Non-EU countries far outstripping exports to the EU. The same is true for the Chemical sector, except that the growth is more moderate ( 1 per cent per annum). In both these hightech sectors, Non-EU MNCs are also becoming more globalized, although the EU remains the principal export destination for Non-EU manufacturing companies $\frac{12}{12}$, for EU MNCs, exports from the Electronics sector became increasingly globalized between 1991 and 1998, but exports from the Chemicals sector showed no significant change in their destination pattern, with exports to the EU continuing to account for over 70 per cent of total EU MNC exports.

In contrast to the high-tech MNC-dominated sectors, the Other Manufacturing sector (which grew by approximately 2 per cent per annum) is becoming increasingly Europeanized and less globalized, particularly for LCs, which showed a significant increase in the proportion of their exports going to EU destinations. Although the EU remains the principal 
destination of LC exports generally, accounting for almost 75 per cent of all exports by LCs in 1998, these data have shown that the 'globalization' of Irish exports is stronger in the two sub-sectors (Electronics and Chemicals) where Non-EU MNCs are dominant (see Section 3).

\section{Table 10.4 near here}

Further investigation of the nature of the relationship between FDI and the export performance of indigenous companies is beyond the scope of this Chapter, but it is useful to note the performance characteristics of Irish-owned exporting companies in particular, given the pattern of FDI and the associated destination of exports outlined here. We have highlighted the changing nature of the destination of exports by LCs and noted the dichotomy between sectors based upon the sectoral level of FDI (EU MNCs versus Non-EU MNCs) and the changing export destination patterns (EU versus Non-EU). Given these differences, it is interesting to speculate on the performance characteristics of LCs in the various sectors. In particular, are there differences in the characteristics of LCs that export versus those that do not, as well as between LCs that are European exporters versus those whose exports are more globalized?

A growing body of empirical work has documented the superior performance characteristics of exporting companies relative to non-exporters (Bernard and Wagner: 1997,

Bernard and Jensen: 1999) $\frac{13}{13}$. In the context of Europeanization and globalization, we can speculate on the whether exporting LCs exhibit superior performance characteristics compared with non-exporting LCs and, secondly, whether LCs that are more globalized in their export patterns have superior performance characteristics to those that are more Europeanized.

To examine the nature of LCs that export compared with those whose sole export markets are European, we list the mean value of five characteristics for the two groups in Table 10.5: Employment, Average Earnings, Gross Output, Net Output, and Net Output per 
Employee. In all instances the mean values for European exporters are higher than for nonexporting LCs. On average, exporting companies are larger, pay higher wages, produce more output, and are more productive than non-exporting LCs in the manufacturing sector.

Our analysis of the changing destination of Irish manufacturing exports has highlighted the Europeanization of export patterns in the Other Manufacturing sector and the globalization of exports in the Chemical and Electronic sectors. The dominance of the UK and to a lesser extent the EU generally as a traditional export destination for Irish manufactured goods suggests that LCs find it easier to export to the EU. However, the increasing importance of export destinations other than the EU may be reflected in superior performance characteristics for non-EU destination exporters, because they are forced to be more competitive and efficient in order to break into these non-traditional markets. Table 10.5 also shows the mean characteristics for LCs that export to Non-EU countries (whether or not they export to the EU as well) between 1991-98. The mean value of each characteristic is higher for the Non-EU exporters, suggesting that, on average, global exporters employ more people, pay higher wages, produce more gross output, and are more productive than LCs that export only to the EU. In effect, the global exporters exhibit stronger performance characteristics than those companies that export only into the EU.

\section{Table 10.5 near here}

In this section we have considered the changing nature of company ownership and the destination of exports by both local and foreign-owned companies in three sub-sectors of the Irish manufacturing industry. By disaggregating the manufacturing industry we are able to note the significant differences in ownership and export destination patterns: in those sectors where Non-EU MNCs dominate (Electronics and Chemicals) Irish-owned company exports have become more globalized. In contrast, in the more traditional sectors where Irish or EUowned companies are dominant, exports are increasingly Europeanized. Moreover, those 
Irish companies that are global exporters show better average performance characteristics than those that are European exporters.

The analysis conducted in this Chapter suggests the need for further investigation into a host of issues surrounding the nature of FDI and its influence on indigenous companies and their export ability and performance. Does the presence of foreign-owned companies have an impact on the export performance of domestic companies? The strong presence of MNCs in sectors such as Chemicals and Electronics in Irish manufacturing may provide market access spillovers that enable domestic companies to become more successful exporters (Greenaway, Sousa, and Wakelin, 2001). Do MNCs have any influence on the probability of an Irish company becoming an exporter and, by extension, the export intensity of Irish companies once they decide to export? What influence, if any, do MNCs have on export destination patterns? If, as appears to be the case in Electronics, Irish LCs are becoming engaged in global sub-supply, how will this impact on the future pattern of export destinations? The proposed addition of new members to the EU in coming years, along with the increasing strength of the EU monetary union, may have profound implications for both the nature of FDI and the destination of exports for small member states such as Ireland. (See Chapter 11 by Kierzkowski in this volume)

\section{Concluding Remarks}

One feature of the enhanced global integration over the past decade has been the increased awareness by countries of global competitiveness. At this point every country in the OECD monitors indicators, however crude, of competitiveness in peer economies and this monitoring process impacts on domestic economic and social policy making. These indicators cover increasingly wider ranges of variables, reflecting the importance being attached to global competitiveness and the complexity of what feeds into determining 
competitive advantage. Given the direction of the data in Tables 10.1 and 10.2, this development is not surprising - countries are increasingly conscious of the upward trend in openness for the design of economic and social policies, with globalization often seen as a constraint on national taxation and welfare policies (See Chapter 12 by Atkinson in this volume).

We noted earlier that the discussion around globalization has focused in the main on large companies - on global MNCs. The emergence of genuinely global MNCs is a natural product of the creation of global markets. While some of these MNCs are growing organically, many are growing through mergers and acquisitions (M\&As) as the constraints set by national governments on M\&As no longer have meaning when geographical markets cannot be sensibly defined in national terms. The issues raised by global competition point to the need for further development in global governance, as raised by Breton and Ursprung in Chapter 13 of this volume

The main thrust of this paper has been to look at the possible influence of Globalization and Europeanization on what is perceived to be a highly globalized economy, namely, Ireland. But the nature of the globalization process for Ireland is complicated by its membership of the EU; by looking in more detail at the Irish manufacturing sector we have attempted to separate the influence of Europeanization from Globalization for this small, highly open economy. We noted the distinction between EU and Non-EU MNCs as the source of Irish FDI, with Non-EU FDI being concentrated in the high-tech Electronic and Chemical sectors; EU FDI has remained principally in the lower-tech and more traditional areas of Irish manufacturing, where local companies also remain concentrated. Although all MNCs located in Irish manufacturing are highly export-orientated they tend to service different foreign markets. The EU-owned MNCs are consistently EU-orientated, while Non- 
EU MNCs are showing greater export growth to the Non-EU markets, although the EU remains their dominant export market.

Ireland established itself as an export platform for MNCs in Europe in the 1970s at a time when its LCs were minimally engaged in exporting, having established strong domestic markets behind high tariff barriers. This Chapter demonstrates that thirty years later, Ireland's LCs are now increasingly export-oriented, with a progressively larger share of their output going beyond the traditional UK market to the enlarging EU market. As the next phase of EU enlargement occurs, Irish LCs will face increasing competition from Eastern Europe on EU product markets; when taken together with increased competition in the EU for mobile MNC investment, this product market competition will place increasing competitive pressure on Ireland.

Our analysis indicates that, on average, the more globalized LCs in Ireland are stronger in terms of company characteristics than the LCs that export into the EU only or that do not export at all. While this raises the question of causation - are the companies stronger because they export or are only the stronger companies capable of exporting? - it points to a positive link between Europeanization and particularly globalization and dynamics at the company level. If Europe is to develop a faster growing economy, such positive dynamics are crucial.

It is clear from Europe's recent history that the energy behind and enthusiasm for economic integration lies in the drive to create greater political stability in the region through increased political interdependency - what group of economists could have persuaded policy makers in Europe to adopt the single market programme on the basis of potential welfare improvements based on very simple calculations of welfare triangles? It is precisely because policy makers wished to find arguments for further economic integration that they were led to accept so readily the results produced as part of the Cecchini Report. Economists are not 
traditionally blessed with such broad and rapid acceptance for their analyses and such little ex-ante or ex-post questioning of the accuracy of their estimates! Structures within Europe have led to increased openness among European countries, reflecting Europeanization more than Globalization. The increasing emphasis in many fora on the need for Europe to become a significant economic and political power block (to counteract the global dominance of the US) is likely to make Europeanization rather than Globalization a priority over the coming decade. Whether such Europeanization promotes the process of Globalization or occurs at its expense, especially for small highly-open economies traditionally focused upon the European marketplace, remains an open question. 
Figure 10.1: Economic Globalization

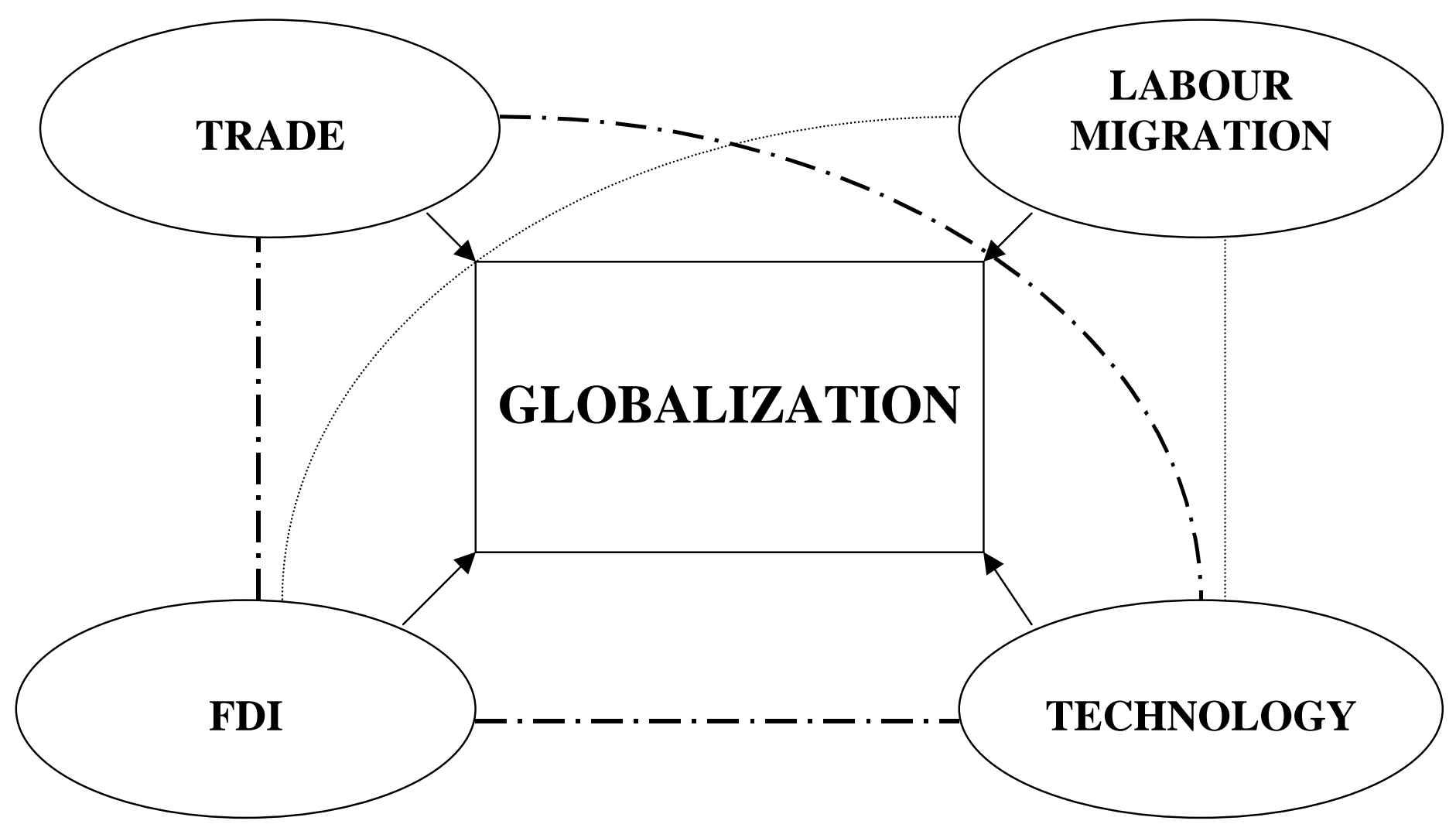


Table 10.1: Ratio of average merchandise exports and imports to GDP, 1970-2000 (percent)

\begin{tabular}{lccccc}
\hline Country & 1970 & 1980 & 1990 & 1998 & 2000 \\
\hline France & 13.0 & 18.9 & 18.9 & 20.7 & 23.0 \\
Germany & 17.4 & 23.5 & 25.1 & 23.7 & 28.0 \\
Italy & 13.1 & 19.9 & 16.1 & 19.8 & 22.1 \\
Netherlands & 42.8 & 50.4 & 45.5 & 50.9 & 55.7 \\
Belgium-Luxembourg & 45.5 & 56.9 & 60.9 & $66.2^{\mathrm{a}}$ & - \\
United Kingdom & 16.7 & 21.0 & 21.0 & 21.6 & 21.8 \\
Ireland & 33.8 & 48.7 & 48.8 & 67.5 & 67.8 \\
Denmark & 24.0 & 26.6 & 25.3 & 26.7 & 28.7 \\
Sweden & 20.5 & 25.6 & 24.3 & 34.1 & 35.1 \\
Austria & 21.6 & 26.7 & 28.3 & 30.9 & 35.1 \\
Norway & 24.5 & 28.0 & 26.5 & 26.0 & 27.9 \\
United States & 4.2 & 8.9 & 8.2 & 9.9 & 10.3 \\
Japan & 9.4 & 12.8 & 8.8 & 8.8 & 9.0 \\
Australia & 12.5 & 13.8 & 13.8 & 16.5 & 17.3 \\
\hline Notes: & & & & & \\
\hline
\end{tabular}

Notes: ${ }^{\mathrm{a}}$ This figure for Belgium-Luxembourg refers to 1997 due to unavailability of data.

Source: Merchandise export and import figures from International Monetary Fund (2001).

GDP figures up to and including 1998 are from the website related to Lane and Milesi-

Ferretti (2001). GDP figures for 2000 are from OECD website. 
Table 10.2: Ratio of average inflows and outflows of FDI in merchandise goods to GDP per period, 1970 - 2000 (percent)

\begin{tabular}{|c|c|c|c|c|c|c|c|}
\hline Country & $70-74$ & $75-79$ & $80-84$ & $85-89$ & $90-94$ & $95-00$ & $70-00$ \\
\hline France & 0.7 & 0.8 & 0.9 & 1.8 & 3.5 & 6.3 & 2.3 \\
\hline Germany & $1.2^{\mathrm{a}}$ & 0.8 & 0.7 & 1.3 & 1.3 & 5.0 & $1.7^{\mathrm{b}}$ \\
\hline Italy & 0.6 & 0.4 & 0.6 & 0.7 & 0.9 & 1.4 & 0.8 \\
\hline Netherlands & 5.2 & 3.7 & 4.3 & 5.6 & 7.5 & 18.3 & 7.4 \\
\hline Belgium-Luxembourg & 2.2 & 2.1 & 1.5 & 4.4 & 7.4 & 22.8 & 6.7 \\
\hline United Kingdom & 3.2 & 3.4 & 3.0 & 6.0 & 4.1 & 12.0 & 5.3 \\
\hline Ireland $^{\mathrm{c}}$ & 0.7 & 2.0 & 1.1 & 0.3 & 2.8 & 8.1 & 2.5 \\
\hline Denmark & 0.9 & 0.3 & 0.4 & 1.3 & 3.0 & 10.8 & 2.8 \\
\hline Sweden & 0.8 & 0.7 & 1.4 & 4.1 & 4.5 & 14.3 & 4.3 \\
\hline Austria & 1.8 & 0.4 & 0.5 & 0.7 & 1.4 & 3.4 & 1.2 \\
\hline Norway & 1.1 & 1.4 & 1.0 & 2.0 & 1.7 & 5.6 & 2.1 \\
\hline United States & 0.7 & 1.0 & 0.9 & 1.6 & 1.6 & 3.2 & 1.5 \\
\hline Japan & 0.3 & 0.3 & 0.4 & 1.0 & 0.8 & 0.6 & 0.6 \\
\hline Australia & 2.0 & 1.2 & 1.6 & 4.2 & 2.5 & 3.5 & 2.5 \\
\hline
\end{tabular}

${ }^{\mathrm{a}}$ Refers to $1971-74$.

${ }^{\mathrm{b}}$ Refers to $1971-2000$.

${ }^{\mathrm{c}}$ Inflow and outflow data for Ireland from 1998 onwards have been amended to take account of changes in the methodology and coverage.

Source: Inflow and outflow data and GDP data up to an including 1998 are from the website related to Lane et al. (2001). Data for 1999 and 2000 for inflows and outflows come from the IMF 2001 and data for GDP come from the OECD website. 
Figure 10.2: Comparison of Irish and EU growth rates, 1970-2000.

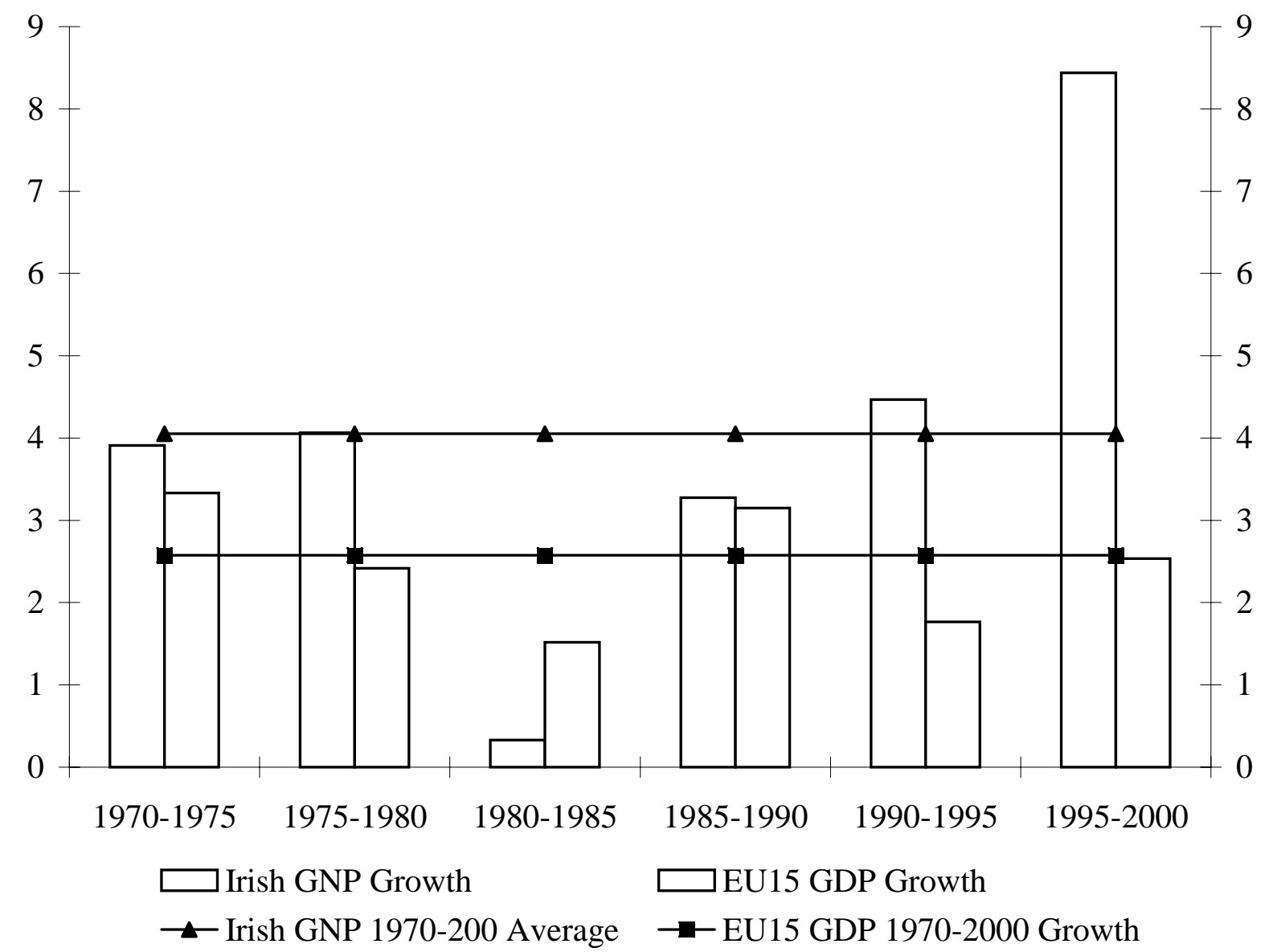


Figure 10.3: Distribution of employment in Irish Manufacturing, by ownership, 1991-98.

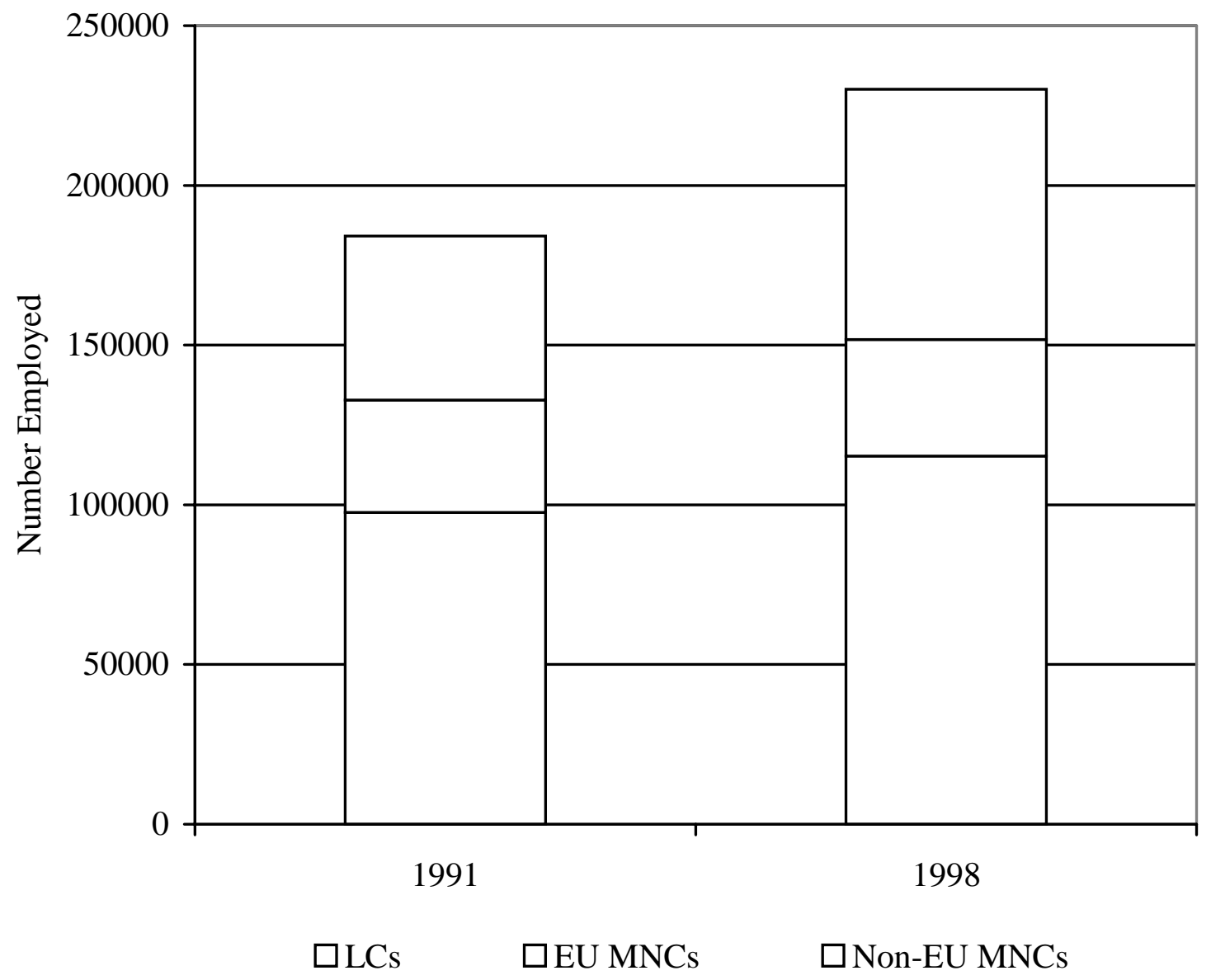

Source: CSO Census of Local Units. 
Figure 10.4: Distribution of Irish manufacturing exports by ownership and destination, 199198.

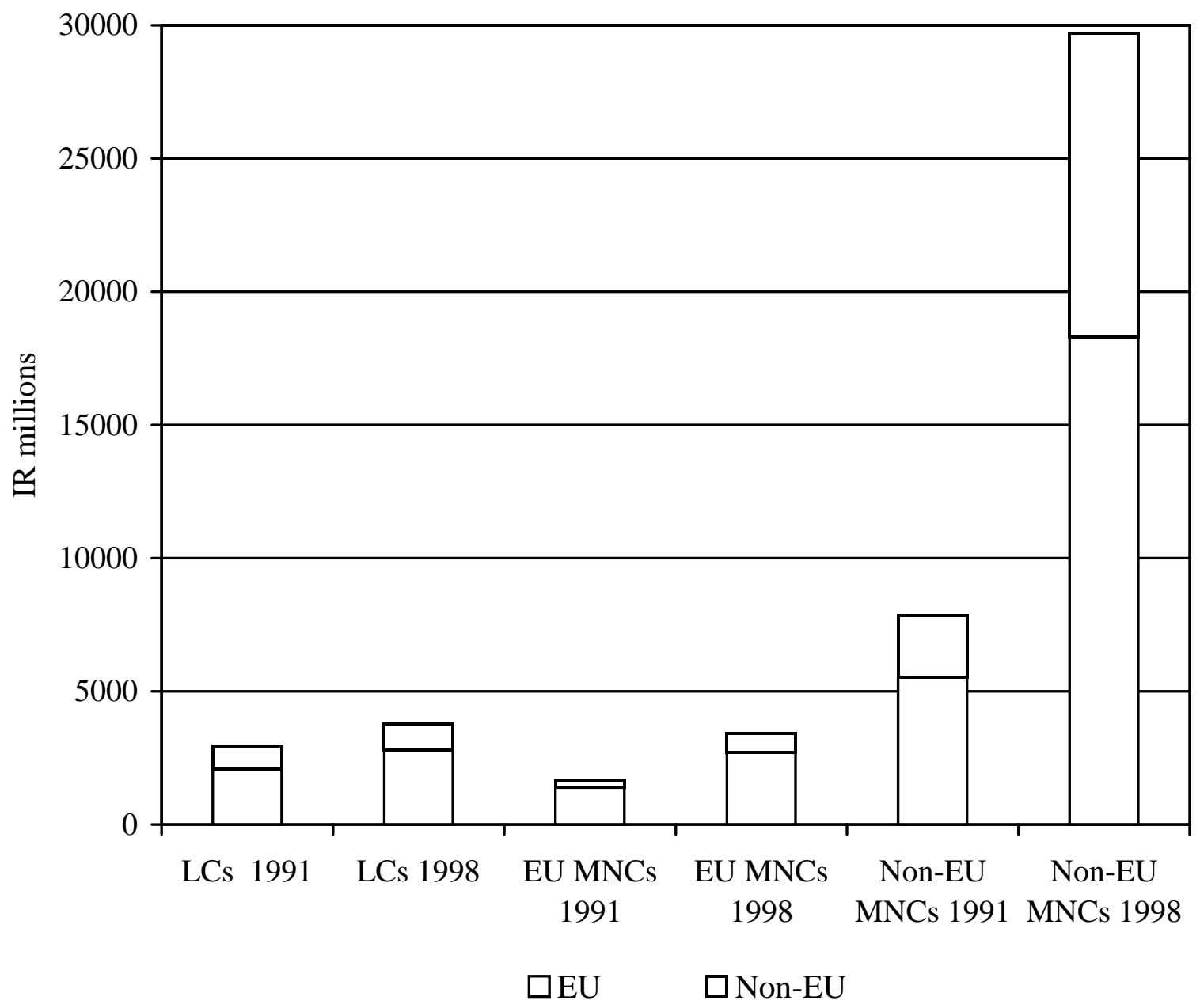

${ }^{\text {a }}$ Deflated where appropriate, $1985=100$.

Source: Own estimates derived from the CSO Census of Local Units. 
Figures 10.5: Distribution of sectoral employment in Irish manufacturing, by ownership, 1991-98.

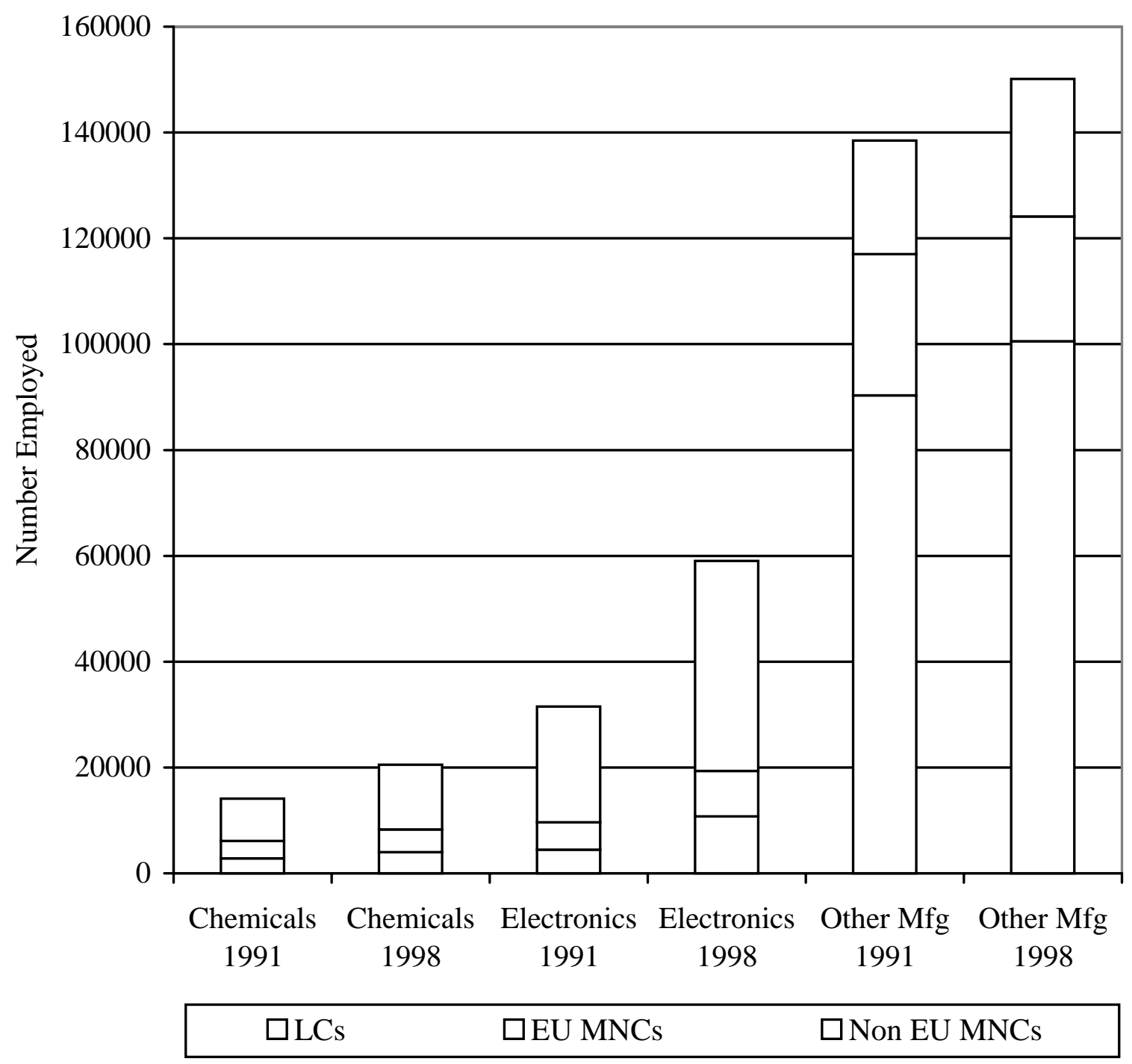

Source: CSO Census of Local Units. 
Table 10.3: Ireland's share of U.S. FDI outflows, 1998

$\%$ of FDI to Europe

$\%$ of FDI to World

Manufacturing

7.0

4.4

Chemicals

15.4

9.1

Electronics

39.2

15.3

Source: US Department of Commerce. 
Table 10.4: Distribution of sectoral exports in Irish Manufacturing, by ownership and destination, 1991-98 .

EU Non-EU EU Non-EU

Chemicals

$\begin{array}{lcccc}\text { Irish Companies } & 93.2 & 6.8 & 82.1 & 17.9 \\ \text { EU MNCs } & 73.4 & 26.6 & 72.6 & 27.4 \\ \text { Non-EU MNCs } & 63.5 & 36.5 & 52.9 & 47.1\end{array}$

Electronics

$\begin{array}{lcccc}\text { Irish Companies } & 82.9 & 17.1 & 49.7 & 50.3 \\ \text { EU MNCs } & 90.8 & 9.2 & 80.8 & 19.2 \\ \text { Non-EU MNCs } & 72.8 & 27.2 & 65.7 & 34.3\end{array}$

Other Mfg (incl. Food)

Irish Companies

EU MNCs

Non-EU MNCs
68.5

31.5

76.5

82.9

75.3

\footnotetext{
${ }^{a}$ Deflated where appropriate: $1985=100$
}

Source: Own estimates derived from the CSO Census of Local Units. 
Table 10.5: Mean characteristics for exporters versus non-exporters of Irish-owned manufacturing companies, 1991-98 ${ }^{\mathrm{a}}$.

Non-exporters EU-only Exporters $\quad$ EU and/or Non-EU
exporters

\begin{tabular}{lccc} 
Employment & 40 & 56 & 86 \\
Average earnings & $£ 10,239$ & $£ 10,402$ & $£ 11,125$ \\
Gross output & $£ 2,942,229$ & $£ 4,293,168$ & $£ 8,779,135$ \\
Net output & $£ 1,039,935$ & $£ 1,495,585$ & $£ 2,625,437$ \\
Net output per employee & $£ 23,375$ & $£ 24,850$ & $£ 28,459$ \\
\hline
\end{tabular}

${ }^{a}$ Deflated where appropriate, $1985=100$.

Source: Own estimates derived from the CSO Census of Local Units. 


\section{References}

Arndt, Sven and Kierzkowski, Henryk (2001). Fragmentation: New Production Patterns in the World Economy. Oxford: Oxford University Press.

Baily, Martin Neil and Robert M. Solow (2001). 'International Productivity Comparisons Built from the Firm Level'. Journal of Economic Perspectives, 15/3: 151-172.

Baltagi, B. (1995). Econometric Analysis of Panel Data. Chichester: John Wiley and Sons Barry, Frank (ed.) Understanding Ireland's Economic Growth. London: Macmillan, 1999. Bernard A and J Jensen (1999). 'Exceptional Exporter Performance: Cause, Effect or Both?' Journal of International Economics, 47/1:1-25.

Bernard, A and Wagner J (1997). 'Exports and Success in German Manufacturing'. Weltwirtschaftliches Archiv, 133/1:134-157.

European Commission (1990). 'Social Europe: The impact of the Internal Market by Industrial Sector: The Challenge for Member States'. European Economy, Special Edition, Brussels.

European Commission (1996). 'Economic Evaluation of the Internal Market'. European Economy, Report No 4, Brussels.

European Commission (1997). ‘The European Union as a World Trade Partner'. European Economy, Report No 3, Brussels.

Feenstra, Robert C. (1998). 'Integration of Trade and Disintegration of Production in the Global Economy'. Journal of Economic Perspectives, 12/4: 31-50.

Kearney, A.T. Inc and the Carnegie Endowment for International Peace (2002).

“Globalization’s Last Hurrah?” Foreign Policy, January/February, pp38-51.

Görg, Holger and Ruane, Frances (2001). 'Multinational Companies and Linkages: Paneldata Evidence for the Irish electronics sector'. International Journal of the Economics of Business, 18/1: 1-18. 
Görg, Holger and David Greenaway (2001). 'Foreign Direct Investment and Intra-Industry Spillovers', Paper delivered to UNECE/EBRD Export Meeting on Financing the Benefits of FDI and Improving the Flow of Corporate finance in the Transitional Economies, December. Geneva: UNECE Mimeo.

Görg, Holger and Frances Ruane (1999). 'US Investment in EU Member Countries: The Internal Market and Sectoral Specialisation'. Journal of Common Market Studies, 37/2: 333348.

Greenaway, David, Sousa, Nouno and Katherine Wakelin (2001). 'Do Indigenous Firms Learn to Export from Multinationals?' University of Nottingham, Mimeo.

Greenaway, David and David Sapsford (1994). 'What does Liberalisation Do for Exports and Growth?'. Weltwirtschaftliches Archiv, 130/1:152-174.

International Monetary Fund (2001). International Financial Statistics - CD Rom. Washington D.C.: International Monetary Fund.

Krugman, Paul R. (1997). 'Good News from Ireland: A Geographic Perspective' in Alan Gray (ed.), International Perspectives on the Irish Economy. Dublin: Indecon.

Lane, Philip R. and Gian Maria Milesi-Ferretti (2001). 'The external wealth of nations: measures of foreign assets and liabilities for industrial and developing countries'. Journal of International Economics, 55/2: 263-294.

Obstfeld, Maurice (1998). 'The Global Capital Market: Benefactor of Menace?'. Journal of Economic Perspectives, 12/4: 9-30.

Richardson, J.D., and K. Rindal (1995). Why Exports Really Matter! Washington D.C.: The Institute for International Economics and the Manufacturing Institute.

Rodrik, Dani (2000). 'How Far Will International Economic Integration go?' Journal of Economic Perspectives, 14/4: 177-186. 
Ruane, Frances and Görg, Holger (1997). "The Impact of Foreign Direct Investment on Sectoral Adjustment in the Irish Economy", National Institute Economic Review, No. 160: 76-86.

UNCTAD (2001). World Investment Report 2001 Promoting Linkages. Geneva: United Nations.

Williamson, Jeffrey G. (1998). 'Globalization, Labour Markets and Policy Backlash in the Past'. Journal of Economic Perspectives, 12/4: 512-72.

\footnotetext{
* We are grateful to the Irish Central Statistics Office for data assistance and to Ali Ugur for research assistance in preparing this paper. The usual disclaimer applies.
}

\section{Endnotes}

${ }^{1}$ The Oxford English Dictionary describes 'global' as "Pertaining to or embracing the totality of a number of items, categories, etc.; comprehensive, all inclusive, unified total; spec. pertaining to or involving the whole world; worldwide, universal". It cites $\underline{\text { Harper's Magazine (1892) }}$ as the first use of global in the present context: "M. de Vogüé loves travel; he goes to the East and to the West for colors and ideas; his interests are as wide as the universe; his ambition, to use a word of his own, is to be 'global'". The earliest reference to Globalization in book titles in the Journal of Economic Literature Index occurs in 1985 .

${ }^{2}$ The A T Kearney/Foreign Policy Magazine Globalization Index ranks the 20 most global nations for the year 2000 .

${ }^{3}$ See Barry (1999) and Krugman (1997). 
${ }^{4}$ The particularly high openness ratios for Belgium and the Netherlands are likely to be partially explained by their hosting key entry freight ports in mainland Europe.

${ }^{5}$ We take annual averages over five year periods (six years in the case of 1995-2000) in order to take account of the large inter-year variations in the flows.

${ }^{6}$ The AT Kearney/Foreign Policy Globalization Index ranked Ireland, Switzerland and Sweden as the most globalized countries in the world for the year end 2000. See Kearney et al. (2002).

${ }^{7}$ Ruane and Görg (1997) draw a similar distinction.

${ }^{8}$ These sectors are described as high-tech in terms of the standard OECD classification - it does not mean that the particular activities being undertaken in Ireland are necessarily very high tech.

${ }^{9}$ The Other Manufacturing component of Irish manufacturing is sometimes segmented for analysis into Food Processing and Other. In our study, the employment and exporting patterns of Food Processing did not significantly differ from those of Other Manufacturing overall and thus we have aggregated the two.

${ }^{10}$ These include several of the sub-sectors in Ireland that the European Commission indicated would be most affected by the single market policy. See European Commission: 1990.

${ }^{11}$ Evidence on the links between MNCs and LCs is discussed in Görg and Ruane (2001).

${ }^{12}$ As Barry (Chapter 9 in this volume) notes, intra-industry trade across all industry subsectors in Ireland, particularly Chemicals and Machinery, has been rising since 1961. Within the Electronics sector in particular, anecdotal evidence would suggest that components trade between US-owned MNCs based in Ireland and their parent company may comprise a significant proportion of the Non-EU export data quoted. However, although exports to the USA by US-owned MNCs based in Irish manufacturing rose from 9 per cent in 1991 to 14 
per cent in 1998, they comprised the smallest proportion of exports relative to the UK (15\%), the EU (48\%), and Elsewhere (24\%) in 1998.

${ }^{13}$ Such econometric studies have shown that exporting plants in the USA and Germany are larger, more productive, and pay higher wages than non-exporters. 